\title{
Participation in Public Space Renewal. Case Study of Poznan - Large City in Poland - A Report
}

\author{
Arch. Bartosz Kazmierczak, PhD \\ bartosz. kazmierczak@put. poznan.pl \\ Arch. Dominika Pazder, PhD \\ dominika.pazder@put. poznan.pl \\ Poznan University of Technology, Faculty of Architecture, \\ M. Sklodowska-Curie Sq. 5, 60-965 Poznan, Poland
}

\begin{abstract}
In the paper there are presented questions of public space renewal, especially within a city centre. The authors present a case study of a city of Poznan in which a number of actions are taken in a field of spatial revival There is accentuated that the most important task is to provide spatial alterations long with social interest and involvement. It is the participation of city inhabitants the most crucial aspect of public space renewal process.
\end{abstract}

Keywords: participation, urban renewal, public space.

\section{Introduction}

In the following paper the author presents the individual interpretation of the conference topic - holistic approach to urban renewal in Polish conditions. Referring to the current spatial situation and Polish planning law in force, there is a need to accentuate that there is either lack of social participation within a planning process or a social consciousseness of spatial development and renewal problems. According to this, in author's opinion, it is crucial to support Polish planning system with soft activities aiming at a promotion of wide social participation within planning system, especially at a local scale. It is needed to make local society feel responsible for the space, not only within neighborhoods but also public areas. Holistic approach to urban renewal in Polish conditions means to make people feel part of planning system, believe their voice is important and understand they havea real impact on changes. The author cooperates with the City Council of Poznan and with non-governmental organization so as to promote participatory planning idea and promote the knowledge about the importance of holistic approach to city space renewal - not only economic but above all spatial and social aspects.

Social participation in the process of urban renewal, especially on a local level, is an essential factor of its proper course and successful conclusion. Although the final form of an urban renewal program is a result of state units' decisions, it always needs consultation and societal acceptance. It should be in progress in the preliminary phase of development of such a program, so the local community have a chance to present their views, identify needs, preferences and aspiration, as well as to develop self-awareness of the assemblage.

The Polish Law on Spatial Planning and Development in force, which was adopted in 2007, contains a record of the obligation of public consultation of planning documents (study of a spatial development and a local plan) which are in the preparation. Local community involvement is expressed in the possibility to make proposals, amendments and objections. It guarantees a social participation in the spatial planning, but it is limited to issuing opinions upon professional preassumptions during the public inspection period of statutorily specified time. At present, several state agencies are obliged 
to presenting their opinion: municipal commission of urban planning and architecture, regional board, the province governor, the county governor, authorities of adjacent communes, provincial conservation officer, military authorities, border protection units and national security, maritime Office, mining and geological supervision office and the Minister of Health. In the same time, there is a lack of the obligation to put spatial planning documents to wider social consultation, which seems to be an important complement to spatial planning processes.

Social participation should primarily address those social groups which are directly involved in the planning process or will experience the effects of certain decisions. These include residents of a given commune, a city or a district, various groups of interest: property or land owners, road users, but also the elderly and disabled, business entities: potential investors, developers, local politicians and representatives of scientific and cultural circles.

\section{Social participation in the process of urban renewal}

All activities related to the transformation of urban space should be held with the participation and social interest. There is a need to sensitize city users to the value anthropogenic environment and to build in public awareness belief in the importance of protecting and emphasizing individuality of the space. That increases the sense of identification with the place, and thus belonging to a particular community. In the process of creation of an urban space it should be taken into account not only the visual effect, but even more so societal impact that is a consequence of certain project decisions. Each space, formed in a particular urban layout and developed by architectural elements in a three-dimensional system, should be a carrier of intangible assets and semantic content. The meaning of an urban space, public space in particular, should refer to needs, aspirations and expectations of a community, to whom it may serve, so it is by nature unique. For this reason, in the process of creation of such an urban space standardized models and solutions may not work, because each space has got defined, individualized features that should be emphasized. In this respect, a necessary factor of a proper spatial planning procedure is adequate socialization of the planning process of transformation and renewal of an urban space, especially a public space. Urban revitalization and renewal programs require consultation and social acceptance. It is crucial for creating an area with which users want to identify with and which strengthens their sense of belonging, a sense of place and a sense of spatial order.

The participation of local communities in the process of planning is especially important in the early stages of a project or an urban renewal program. As a result, the community have the opportunity to present their point of view, identify needs, preferences and aspirations. Participation relates primarily to the people directly involved in the planning process in the future or likely to feel its effects. These include residents, property or land owners, road users, potential investors, local politicians, representatives of scientific and cultural circles, but also the elderly and disabled. Proper organization of public participation is extremely important, especially in terms of building the identity of the place, interpersonal bonds and good relationships, in mitigating social conflicts and eliminating manipulation and abuse in fulfillment of particular interests. It is important to prepare the representatives of local authorities to conduct mediation, which will assure that obtaining individual benefits or realization of interest of a particular political party will not become an obstacle to the implementation of general social benefits. Negative assessment of spatial transformation process is usually issued to arbitrarily imposed forms of changes.

Regulation and organizing of spatial processes should not rely on excessive expansion of bureaucracy, but resort to the support of experts who can professionally analyze existing conditions and formulate directions, principles and methods of implementation of spatial transformations. It is important to define the boundaries of top-down management, to protect and develop the ability of local communities to self-organize and apply a real concern for the common good, which here is the space. Strategies and local policies should support efforts to the socialization of the process of programming the transformation and revitalization, and space management [Wiszniowski, 2014].

The socialization of the process of planning was reflected in contemporary planning models [Parysek, 2006], inter alia communicative planning [Sager, 2002], collaborative planning [Healey, 2003], planning through debate [Fainstein, 2000] or participete planning [Sanoff, 2000]. There are also other, developed in mature, democratic civil environments, methods of 
public participation in planning processes, such as charrette ${ }^{1}$ workshops. The principle of the workshop is to replace the top-down decision-making process with a so-called "from scratch" approach. The essence of the workshop is a collaboration of entities in order to build consensus and solutions according to the needs of all stakeholders. Charrette principle is a dialogue in which participants have a chance to know and understand the needs of each party and to support a shared vision of the project.

\section{Participation supporting public space renewal in Poznan city - author's experience}

The author of the study co-initiated, co-authored and participated in a number of projects aimed at promoting new solutions for the socialization of the process of programming the revitalization in Poznan, and also actions calculated to perfect the processes of planning and urban space renewal. In these activities involves many different units dealing with problems of revitalization - first and foremost Department of Project Coordination and Revitalization of the City Council of Poznan, also cultural centers, foundations, associations, district councils and other non-governmental organizations. The basic assumption of those initiatives is to seek innovative solutions based on the participation of multidisciplinary teams of specialists and the involvement of local communities in the processes of sustainable development and urban space renewal, with an emphasis on public space.

\section{International Urban Workshop in 2007}

An interesting pilot project in terms of the socialization of the renewal process of Poznan city was an international urban Charrette workshop, organized at the Faculty of Architecture of Poznan University of Technology. They were prepared and carried out in cooperation with the Department of Project Coordination and Revitalization of the City Council of Poznan. During the workshop, Polish, Slovak and German students worked on the concept on renewal of a fragment of downtown in Poznan. The aim of the workshop was a dialogue and understanding in order to initiate an integrated process planning and urban design, comparing the various methods of construction of the program, as well as phasing and realization of an urban project, that is normally harnessed by individual research centers, and therefore, creating the optimum model of programming of renewal processes. Students were representatives of various disciplines - architecture and urban planning, spatial planning and economics. The assumption of a Charette was to develop a methodology of design on the areas subject to renewal programs with particular regard to minimizing conflicts between investors, municipality and local community. Moreover the aim was to define the role of an urbanist in the planning and organization of the revitalization program, and to determine his role in the processes of development and renewal of cities. At the stage of building a sustainable renewal program, representatives of the City of Poznan, the company Echo Investment and the representativ es of a local community - District Council of the Old Town were asked to comment and to give opinion in order to correct the students' work and to give the project the most real dimension. That elaboration became the basis for a broad discussion on the responsibility for space and the need for the involvement of many different partners in the design process and construction downtown revitalization program.

\section{The Game of Space - Seminar about Public Space 2008}

"The game of Space" was another project organized in collaboration with the City of Poznan and professionals in other disciplines - sociologists and economists. The main idea was to test the fields of interest of groups involved in shaping processes of urban public spaces: the residents, investors and representatives of local authorities. It was also to identify areas of convergence of interests and fields of conflicts, to enable better understanding of intentions in decision-making of the various interest groups in regards to management and use of public spaces. The experiment was based on isolating groups on separate panels and simulating the planning of new investments in two selected areas of the city. "Stakeholders" have at their disposal the shares, with which they were able to fill in investment fields. After filling in all the fields of investment players they had to determine the percent of the build-up area of the field and its height. On the second day the results were confronted and discussed. Particular groups of "The game of Space" could observe the effects of their actions and hear justifications of their competitors. As a result, different groups of interest could better understand their arguments

\footnotetext{
${ }^{1}$ Charette w orkshops are related directly with New Urbanism (The Congress forNew Urbanism - CNU). CNU has a significant impact on the w orld's spatial policy, thanks to, among others, Charter of the New Urbanism, an annual congresses and numerous publications.

Source: http://www.charretteinstitute.org and http://www.ceunet. org.
} 
and motivations of action, its often different language, and thus better prepare for discussion upon the proposed solutions. The experiment was intended to raise awareness and to demonstrate to warring groups, that most of the problems are associated with the lack of trust, knowledge and understanding of needs of motivations of other participants in the process of development and use of a public space.

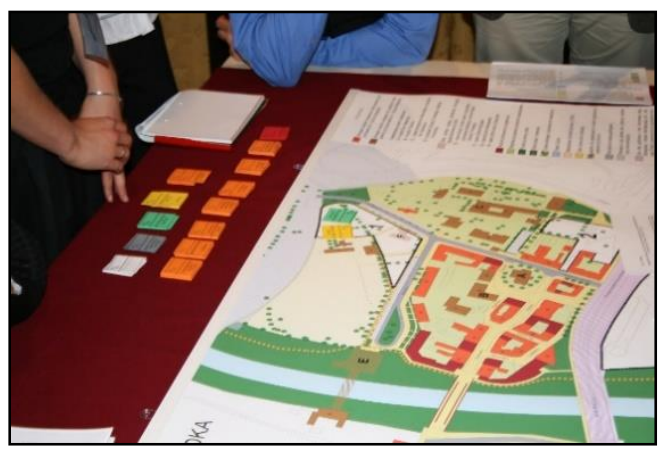

Fig. 1. "The game of Space" project was organized in collaboration with the City of Poznan in order confront different groups of interest and make them collaborate within a game concerning real problems of a given space. Photo by author.

\section{Future City Game. Re-wita Ostrówek - Workshop 2009}

Workshops "Re-vita Ostrówek" on Śródka in Poznan was organized by the District Council Ostrów Tumski - Śródka Zawady, the British Council, Pro Design, Office of Development of Social Relations and Department of Project C oordination and Revitalization of the City Council of Poznan within the project Creative Cities. Among participants were architects, artists, investors and developers, community activists, residents of Śródka and representatives of the city authorities. Players were divided into several interdisciplinary teams, whose task was to develop ideas to revitalize this part of town in ten years perspective and giving them an appropriate hierarchy. After the initial presentation of ideas the teams prepared themselves for testing them in the field and among professionals, residents, officials and invited observers. In this way, developers could verify their ideas and subject them to comprehensive criticism. With such an approach, voters could choose the concept, which in their opinion was approved by all, and yet seemed the most attractive and innovative. In addition to formulating specific solutions, workshop provided an opportunity to exchange views on ways to revive devastated parts of the city, and to meet people that are operating for the same purpose, but in different areas.

\section{Creative Cities - Workshops 2012-1013}

As a very interesting experience for the author can be regarded the participation in the international project CREA. RE Creative Regions, led by Adam Mickiewicz University and financed from EU funds within the uropean Regional Development Fund, Interreg IVC, Innovation and Environment. Participation in this project was the result of an invitation to the author made by the Department of Project Coordination and Revitalization of the City Council of Poznan, to actively participate and substantively support activities of the group set up for this project called Local Support Group for the creative industries in a Group of Creative Space.

The aim of the project was the involvement of local authorities and public and private institutions to promote the creative industries in Poznan. Established within the framework of the initiatives Local Support Group would become a platform for cooperation and exchange of experiences between the different players in the business of creative industries. Many meetings were organized and a series of design workshops held on issues related to educational activities for the public space and the creation of inspiring public space through innovative and interactive solutions in the field of landscape 
architecture ${ }^{1}$. The overall aim of the project CREA. RE was an attempt to find an answer to the question of how to create effective strategies and projects, supporting the development of the creative sector. Recommendations of solutions, developed during meetings and numerous bottom-up initiatives have been collected in the study Local Action Plan for creative industries in Poznan and Wielkopolska Region², which also constitutes a reference to the provisions in strategic documents of higher order, inter alia: Development Strategy for the City of Poznan till 2030, Poznan Agglomeration Development Strategy till 2020 and Development Strategy for the Wielkopolska Region till 2020.

\section{Common does not mean nobody's - Educational and Cultural Project 2014-2015}

Latest venture, in which the author is involved, is a still ongoing educational and cultural project for the public space called the "Common does not mean nobody's". It is a project co-organized by the association called Revitalization Forum, branch in Poznan and the Department of Project Coordination and Revitalization of the City Council of Poznan and additionally financially supported by the Department of Culture of the Poznan City Council, with funds from the Ministry of Culture and National Heritage of 2014.

This project is a continuation and in some ways the culmination of previous operations undertaken in cooperation with the Poznan City Council. It raises awareness of the public space, promotes a sense of ownership of and identification with the space. In October 2008 in Poznan, a seminar on public space was held. Then in May 2009, the scientific conference devoted to public spaces took place under the patronage of the Ministry of Infrastructure, the Mayor of Poznan and the Rector of the University of Technology. The seminar and the conference became stages of preparation of working papers for the Charter of the Public Space - an initiative related to the planned for 2009 in Poznan III Congress of Polish Urbanism. The Charter of the Public Space was supposed to become a disinterested document, programmatic for a creation of Polish public spaces addressed to circles of stakeholders of a public space: investors, communities, local authorities, and, what is important, by those circles formulated. At the conference, a preliminary draft of the Charter of the Public Space was discussed, and the main conclusion was that there is the lack of societal education, especially in the period of preschool and schooling.

Within the framework of the continuation of the actions related to a public space, under the motto "Common does not mean nobody's" (pic. 1), several workshops have been conducted aiming at different age groups: from children, teenagers, students up to seniors. The result of the project was the creation of an illustrated book for adults and children, presenting the most important issues regarding behavior in a public space, answering, inter alia, questions of what the public space actually is and how we should take care of it. The objective was to seek to increase awareness and knowledge of the inhabitants of Poznań on the shaping and quality of public space. The main idea behind the initiative was to develop educational materials for different age groups, for the development and quality of public space based on the records in the Charter of the Public Space, with reference to the specific area of Poznan, but with the possibility of universal use in other cities.

As a result of the workshop, materials from teachers and experts were received, which gave an important information needed for preparation of a book popularizing idea of a public space and the possibilities of its development, addressed to children and adults. The foundation in development of the book both in the substantive, literary and graphic form, was a correspondence of the content with records of the Chart of the Public Space and coherency with the educational materials that were used during the workshops. Each of the topics attempted in the book, in example of an excessive number of cars in the streets, of littering of a public space, of the lack of interesting, visually attractive, ergonomic and economic street furniture, etc., was presented in the form of fold-out pages where the outer side of the text adapted to children, and with an

\footnotetext{
${ }^{1}$ The author is currently a member of the team conducting research within a framework of statutory activities, DS.PB in the y ears 20132015 on the Faculty of Architecture of Poznan University of Technology, entitled "Art in the city - in the context of creation and social activ ation of public spaces. An example of a study of Poznań. Physiognomical and semantic study of the inner-city public spaces of Poznan." Projectleader: dr hab. T. Matusewicz, team: dr Bartosz Kaźmierczak, dr Dominika Pazder.

${ }^{2}$ The publication edited by prof. T. Stryjakiewicz, authors of the study: K.Bogdańska-Gluchowska, O.Hołoga, N.Madajczyk, dr M. Męczyński, dr K. Stachowiak, prof. T. Stryjakiewicz
} 
internal text addressed to adult readers. At this stage of project implementation, 1,600 copies of the book were released and distributed for free among the groups involved in the project - workshop participants.

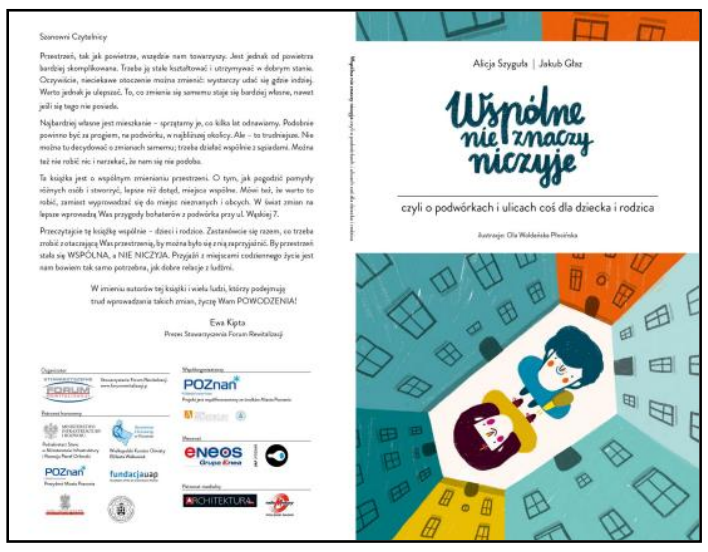

Fig. 2. The from and back covers of a book about public space for children and parents - the outcome of an educational and cultural project for the public space called the "Common does not mean nobody's".

Moreover, it is planned to organize a nationwide conference, during which educational materials for a public space and conclusions of completed workshops will be presented. The aim of the conference is to summarize a series of workshops and provide participants with a feedback from the workshop, the adequacy of educational materials, proposals for changes, etc. For those reasons, amongst the invited guests, in addition to academics, teachers leading the workshops and their participants should be included. During the conference the book on the public space entitled "Common, does not mean nobody's. On backyards and streets, something for the child and the parent. "1. Project will be concluded with a promotional and integrational event, for example. city game (May or's Office), during which all participants of the workshop will be able to meet and confront the acquired knowledge in the urban space in a playful manner. Additionally, a publication of a book on a commercial basis is planned and further distribution to bookshops is intended.

\section{Conclusions}

The most important result of ongoing planning and revitalization processes should be a social consensus to establish the plan and the

Introduction of the solution. In this regard it is important to reconsider the role and responsibility of the architect-urbanist or spatial planner. He cannot be limited only to the creation of space. He must also take into account the need for new challenges in negotiation as well as informational and educational aspects. In this context, it is important to create new theoretical solutions including the possibility of their implementation and use in order to minimize conflicts caused by different aims and interests of various social groups.

Reaction to the social evaluation of urban space is crucial in achieving a certain harmony between the social and the urban dimension of the city. This is particularly important, because the functional and spatial structure of the city is less susceptible to change than inhabiting it community. Shaping the urban structures must cause changes in the functioning of the local community, but also give the opportunity to shape the environment by its users. The socialization of processes of transformation - revival and renewal of urban space - is a precondition for the desired effect of the planning and changes

\footnotetext{
${ }^{1}$ The author of the tex tfor children: Alicja Szyguła, the tex tfor adults: Jakub Głaz, illustrations made by Ola Woldańska- Płocińska, and the author of this article, along with dr Bartosz Kaźmierczak, appeared in a dual role - substantive consultant and a representative of an association Revitalisation Forum, branch of Poznan. The book was published in 2014.
} 
of an urban space and building local identity. What is more, societal acceptance of planned changes in the functional and spatial lay out of the city is not only the guarantee of assimilation of local groups with the new conditions, but also factor that can ensure a harmonious and sustainable development and local economic growth.

\section{References}

[1] Fainstein S. S. (2000) "New Directions in Planning Theory", Urban Affairs Review, March 2000, vol. 35

[2] Healey P. (2003) "Collaborative Planning in Perspective", Planning Theory, Vol. 2, Sage Publications

[3] Kaźmierczak B. (2014) "Social and cultural aspects of a city public space transformation. Case study of Poznan, Poland", MCSER Publishing, Mediterranean Journal of Social Sciences, Vol. 5, No. 19, August 2014, ISSN 2039-9340, Rome-ltaly, p. 411-417

[4] Parysek J. J. (2006) „Wprowadzenie do gospodarki przestrzennej”, Wyd. Nauk. UAM, Poznań

[5] Pazder D. (2013) "From informal to formal in a decision making - creating a creative city centre", Rethinking the Urban, DAKAM, ISBN:978-605-5120-24-5, Istambul, 2013, s. 311-317

[6] Pazder D. (2014) "Innovation and creativity in a design of high quality public space. Case study of Poznan, Poland", MCSER Publishing, Mediterranean Journal of Social Sciences, Vol. 5, No. 19, ISSN 2039-9340, Rome-Italy, p. 405-410

[7] Sager T. (2002) "Democratic Planning and Social Choice Dilemmas. Prelude to Institutional Planning Theory", Urban and Regional Planning and Development Series

[8] Sanoff H. (2000) "Community Participation Methods in Design and Planning", John Wiley \& Sons, USA

[9] Wiszniowski J. (2014) „Wpływ społeczności lokalnych na obraz architektury”, in Przesmycka E. and TrockaLeszczyńska E. (eds), Architektura przyszłości, Wrocławskie Wydawnictwo Naukowe, Wrocław 